\title{
THE FUTURE OF UK-IRISH RELATIONS
}

\author{
Etain Tannam*
}

This article examines the impact of Brexit on the British-Irish intergovernmental relationship and places the assessment in the context of the contemporary history of the relationship. In particular it highlights the importance of the intergovernmental relationship since 1985 and its role in the peace process and the Belfast/Good Friday Agreement. First, the importance of the British-Irish relationship and the $E U$ in achieving a peace process in Northern Ireland is examined and the implications of Brexit are assessed. The challenges of Brexit are then outlined, before Brexit's impact to date is evaluated. Finally, in conclusion, potential methods of managing the relationship between the UK and Ireland after Brexit are outlined and it is argued that stronger use of the British-Irish Intergovernmental Conference is necessary to ensure future cooperation, as well as developing stronger institutional links across a range of policy areas.

Keywords: Brexit, Good Friday Agreement, British-Irish cooperation, British-Irish Intergovernmental Conference

\section{TABle Of CONTENTS}

I. INTRODUCTION. 276

II. THE SIGNIFICANCE OF THE BRITISH-IRISH RELATIONSHIP AND THE EU IN

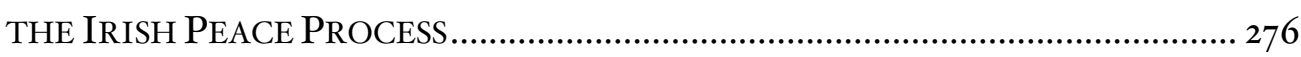

I. Fohn Hume and the '3 Strands Approach' '......................................................... 277

2. The Anglo-Irish Agreement ........................................................................... 279

3. The Belfast/Good Friday Agreement ……………......................................... 28

III. BREXIT'S CHALLENGES TO THE BRITISH-IRISH RELATIONSHIP ............. 284

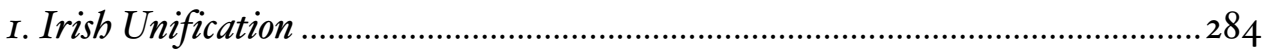

2. The Belfast/Good Friday Agreement ………...................................................28 286

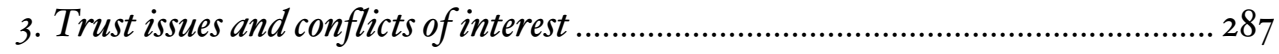

Associate Professor of International Peace Studies at Trinity College Dublin. 
IV. BREXIT AND THE BRITISH-IRISH RELATIONSHIP, 2OI6-2OI9.................... 289

V. THE FUTURE OF THE BRITISH-IRISH RELATIONSHIP .................................. 295

VI. CONCLUSION

\section{INTRODUCTION}

The outcome of Brexit was always going to be a challenge to British-Irish relations, but few would have expected the perfect storm of events that ensued: a weak UK government, a confidence-and-supply arrangement between the British Conservative Party and the Northern Ireland Democratic Unionist Party (DUP), the death of Martin McGuinness, one of the original signatories and negotiators of the Good Friday Agreement, and a collapsed Northern Ireland Executive. The period from June 2016 to March 2019 created great stress in the British-Irish relationship. In this article the importance of the British-Irish relationship and the EU in achieving the peace process in Northern Ireland from 1990 to 1998 is examined and the implications of Brexit are assessed. In Section III, the challenges of Brexit are analysed and, in Section IV, Brexit's impact from June 2016 to March 2019 is evaluated. Finally, in conclusion, potential methods of managing the relationship after Brexit are outlined. In assessing levels of cooperation, the focus is on the rhetoric from both governments.

\section{THE SIGNIFICANCE OF THE BRITISH-IRISH RELATIONSHIP AND THE EU IN THE IRISH PEACE PROCESS}

British-Irish cooperation was central to the success of the peace process in Northern Ireland and the signing of the Belfast/Good Friday Agreement on

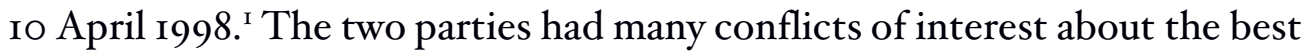
means of achieving peace from the 1960 s to the $1980 \mathrm{os}$, but from the midI980s a process of cooperation developed. ${ }^{2}$ The ' 3 strands approach' to

I David Mitchell, Etain Tannam and Sarah Wallace, '20 Years of the Good Friday Agreement: Political Dimensions' (2008) Irish Political Studies 283-310.

2 Etain Tannam, Cross-Border Cooperation in Ireland and Northern Ireland (Basingstoke Palgrave 1999). 
conflict resolution became central to the peace process, in the context also of EU membership. UK and Irish membership of the EU from 1973 was regarded by many observers as a factor in increasing British-Irish cooperation; as O'Brennan notes, before 1973, no British Prime Minister had visited Ireland since 1921. ${ }^{3}$

\section{Fohn Hume and the '3 Strands Approach'}

Cooperation did not evolve spontaneously, but reflected the strategy of John Hume, former leader of the Social Democratic Labour Party (SDLP), and his influence on Irish policy-making. Hume's ' 3 strands approach' ${ }^{4}$ was based on the argument that the conflict in Northern Ireland was an identity conflict between nationalists, on the one hand, whose democratic rights were not protected in a unionist regime, and unionists, on the other, who feared that they were under threat from irredentist Irish governments and nationalists. The ' 3 strands approach' was based on the argument that the key to resolving the conflict was to reassure both communities that their rights were protected and the key to achieving such reassurance was through ensuring that three sets of relations - or strands - were cooperative: I) relations between communities in Northern Ireland; 2) cross-border relations on the island of Ireland; and 3) relations between British and Irish governments.

Strand I aimed to create democratic, legitimate institutions in Northern Ireland that represented both nationalists and unionists and would respect their rights. Strand 2 would develop institutions to encourage cross-border economic cooperation to maximise economic potential, but also bring about greater social communication and cooperation. Strand 3 was important because the UK and Ireland were kinship states. In other words nationalists looked to the Irish government for protection, but that protection had not been forthcoming up until the outbreak of the conflict. The unionists thus looked to the UK government for protection. By ensuring both communities

3 John O'Brennan, 'Requiem for a Shared Independent Past: Brexit and the deterioration of in UK-Irish Relations' (2019) 5 Capital and Class I-15.

$4 \quad$ 'Hume says new structures are needed and endorses three-strand approach', Irish

Times (August i8 1997) <https://www.irishtimes.com/news/hume-says-newstructures-are-needed-and-endorses-three-strand-approach-I> accessed I October 20I9. 
felt protected their members would be less likely to resort to violence. These strands became integral to the Good Friday Agreement.

In short, conflict resolution in Northern Ireland rested on the totality of the relationship between Ireland, Northern Ireland and Britain. Hume's emphasis on two identities co-existing and on the ability to aspire to be a united Ireland, yet also accept the legitimacy of being in the UK state, was based on his appreciation of the EU as a successful experiment of post-war cooperation. Repeatedly he cited the example of the Franco-German reconciliation, stating that if France and Germany could cooperate after World War II and centuries of hostility, then so too could nationalists and unionists in Northern Ireland. The EU framework of cooperation was vital to identify common economic interests and build trust on that basis within that institutional framework.

In I984, despite the UK government's misgivings, the European Parliament issued a report, known as the Haagerup Report, that defined the conflict in Northern Ireland as an 'identity conflict', thus echoing the Irish government and John Hume's approach. ${ }^{5}$ It was an historic event in that it was the first time the EU became involved in the Northern Ireland conflict. Although it is difficult to provide evidence of the EU's causal role in British-Irish cooperation, or in the peace process itself, ${ }^{6}$ the former's involvement and approach legitimised the Irish government and Hume's idea, making it more difficult for opponents to undermine it.

The identity approach, combined with the conception of Northern Ireland as an example of a failure of majoritarian democracy, contributed to an emphasis on institutionalising the Irish dimension and on British-Irish cooperation as a way to resolve the conflict. By enshrining institutionally an Irish role in policy towards Northern Ireland, nationalists would feel protected; and by ensuring any Irish role was in conjunction with the UK's role, unionists would feel protected. Cross-border cooperation would also reassure both communities about the merits of economic cooperation and increase networking, so that trust increased between nationalists and

5 Katy Hayward, 'Reiterating National Identities: The European Union Conception of Conflict Resolution in Northern Ireland' (2006) 4I(3) Cooperation and Conflict 26I-284.

6 Tannam (n 2). 
unionists. Internally, developing democratic power-sharing institutions in Northern Ireland that represented both communities was central. Strand 3 the British-Irish relationship - was the necessary condition to achieving cooperation in Strands I and 2. Without it, the other levels of cooperation would not develop.

The failure of the Sunningdale Agreement in $1973^{7}$ in the face of unionist opposition created an awareness that unless both British and Irish government stood firm in a joint approach to Northern Ireland, any efforts to create peace would be thwarted by either Sinn Fein, or the DUP. ${ }^{8}$ Thus, in I980 Charles Haughey, then Irish Prime Minister, met with his UK counterpart, Margaret Thatcher, to begin a new era of cooperation.

\section{The Anglo-Irish Agreement}

Under the 1985 Anglo-Irish Agreement, the Anglo-Irish Conference was established. It was the first time in Northern Irish history that a UK government did not yield to unionist pressure not to engage with the Irish government and that both governments supported each other in following through with the agreement. ${ }^{9}$ Thousands of unionists marched against the I985 Agreement, in protest at the Irish role in the Anglo-Irish Conference. However, the Conservative party, led by Margaret Thatcher, refused to yield to the pressure, with both governments stating that the Agreement, unlike the Sunnnigdale Agreement, had been ratified as an international treaty in the UN and could not be revoked except by mutual consent of both governments. As such, the Agreement remained intact. ${ }^{\text {IO }}$

7 The Sunningdale Agreement created a power-sharing executive in Northern Ireland and a Council of Ireland representing the Irish government and Northern Irish devolved government. The Council of Ireland was to have executive powers over key policy areas including policing. Many unionists strongly opposed the Agreement for that reason and the agreement was brought down following a strike by Ulster Workers Council., It was never ratified at the UN, so did not have the status of international treaty.

8 Brendan O'Leary, 'The Limits to Coercive Consociationalism in Northern Ireland' (I989) 4 Political Studies xxxvii 455-65.

9 Ibid.

ro Brendan O'Leary and John McGarry, 'The Politics of Antagonism' (Athlone Press I996). 
The 1985 Agreement comprised seven articles, all of which laid out the role and operation of the Conference, giving the Irish government a consultative role in matters of concern to nationalists. Its areas were listed as political matters, security and related matters, and legal matters, including the administration of justice and the promotion of cross-border cooperation. ${ }^{\text {II }}$ Under article 3, it was stated that:

The Conference shall meet at Ministerial or official level as required. The business of the Conference will thus receive attention at the highest level. Regular and frequent Ministerial meetings will be held and in particular special meetings shall be convened at the request of either side. ${ }^{\mathrm{I}}$

The Anglo-Irish Agreement laid the groundwork for the 1998 Good Friday Agreement, not just in its broad principle of enshrining an Irish role in policy of Northern Ireland, but also in its negotiation process, whereby a joint British-Irish strategy emerged. ${ }^{13}$ Anglo-Irish relations emerged as a central part of that cooperation.

From 1985 onwards senior British and Irish civil servants continued to meet regularly and developed an exceptional working and, in some instances, personal relationship. ${ }^{14}$ Many civil servants observed how, over time, problem-solving became a joint exercise. ${ }^{15}$ Both the conceptualisation of a problem and its solutions emerged organically from both governments and adversarial policy making declined. It was this approach that typified the negotiations that preceded the Good Friday Agreement.

The strategy that emerged from the British-Irish policy process was one coined 'coercive consocationalism'. ${ }^{6}$ The aim was to achieve a consociational settlement in Northern Ireland, implying a power-sharing devolved government that protected the nationalist minority by giving all parties a

II Department of Foreign Affairs and Trade, The Anglo-Irish Agreement (I985) $<$ https://www.dfa.ie/media/dfa/alldfawebsitemedia/ourrolesandpolicies/northerni reland/Anglo-Irish-Agreement-I985.pdf > accessed I October 2019, Art 2.

I2 Ibid Art 3.

I3 O'Leary and McGarry (n Io) 238.

I4 Etain Tannam, 'Explaining the Good Friday Agreement: a learning process' (200I) 36(4) Government and Opposition 493-518.

15 Ibid 500 .

i6 O'Leary (n 8). 
veto over any policy that undermined a vital interest of its community. The coercive aspect referred to the carrot-and-stick strategy of enticing Sinn Fein, the Ulster Unionist Party (UUP), and the DUP to cooperate so as to have democratic power, but threatening to exclude them from negotiations if they did not cooperate. Overall from the mid-r980s the British-Irish relationship was characterised by a joint policy making approach and an emphasis on both governments as honest brokers. ${ }^{17}$ Eventually, this made them co-guarantors of the Belfast/Good Friday Agreement.

\section{The Belfast/Good Friday Agreement}

The Good Friday Agreement was signed on April io I998. It was not simply consociational, but a bespoke version, 'consociation plus', ${ }^{18}$ encompassing Hume's ' 3 strands approach'. Strand 2 of the Agreement provided for the cross-border North-South Ministerial Council representing Irish and Northern Irish ministers and their civil servants to decide policy in six areas of cooperation. Strand 3 resurrected and modified the old Anglo-Irish Conference, but re-named it the British-Irish Intergovernmental Conference. It also provided for a new British-Irish Council to represent Northern Ireland, Ireland, Britain, Scotland, Wales and the Crown Dependencies.

The British-Irish Intergovernmental Conference, 'dealing with the totality of the relationships', ${ }^{19}$ was to meet frequently, like the Anglo-Irish Conference. Unlike the Anglo-Irish Conference, however, the Belfast/Good Friday Agreement stipulated that the British-Irish Intergovernmental Conference was to meet at summit level (that is with both Prime Ministers

17 Etain Tannam, 'Cracks Beginning to Show in British-Irish Relationship' (LSC Blogs, 26 July 2017) <https://blogs.lse.ac.uk/brexit/2017/07/26/cracks-arebeginning-to-appear-in-british-irish-relations/> accessed I4 September 2019.

I8 Brendan O'Leary 'The Twilight of the United Kingdom and Tiocfaidh ar Lá: Twenty Years after the Good Friday Agreement', in Tannam (ed) Beyond the Good Friday Agreement in the midst of Brexit (London Routledge 2018) 2.

is Belfast/Good Friday Agreement (1998) available at <https://www.britishirish council.org/agreement-reached-multi-party-negotiations/strand-3-british-irishcouncil-and-intergovernmental $>$ Strand 3, para I. 
in attendance) 'as requireed', ${ }^{20}$ but otherwise at ministerial level as appropriate. The Council enshrined the Irish government's role:

In recognition of the Irish Government's special interest in Northern Ireland and of the extent to which issues of mutual concern arise in relation to Northern Ireland, there will be regular and frequent meetings of the Conference concerned with non-devolved Northern Ireland matters, on which the Irish Government may put forward views and proposals. These meetings, to be co-chaired by the Minister for Foreign Affairs and the Secretary of State for Northern Ireland, would also deal with all-island and cross-border co-operation on non-devolved issues.

Co-operation within the framework of the Conference will include facilitation of co-operation in security matters. The Conference also will address, in particular, the areas of rights, justice, prisons and policing in Northern Ireland (unless and until responsibility is devolved to a Northern Ireland administration) and will intensify co-operation between the two Governments on the all-island or cross-border aspects of these matters. ${ }^{21}$

Strand 3 also provided for the British-Irish Council, a consultative body to discuss sectoral policy issues, and comprising ministers from Ireland, Northern Ireland, Scotland and the Crown Dependencies as well as the Irish and UK Prime Ministers or their delegates. Its function was to 'promote the harmonious and mutually beneficial development of the totality of relationships among the peoples of these islands. ${ }^{122}$ Furthermore, it was to meet 'at summit level, twice per year; in specific sectoral formats on a regular basis, with each side represented by the appropriate Minister; in an appropriate format to consider cross-sectoral matters. ${ }^{23}$

The EU was also mentioned explicitly in the Agreement under Strand 2. ${ }^{24} \mathrm{~A}$ specific cross-border body, the Special EU Programmes Body, was created to administer EU funding. However, the EU's implicit relevance was far greater than the explicit relevance. The multi-level non-territorial conception of identity and the functional logic of cooperation were regarded as important contextual factors in the Agreement not simply for Northern Ireland, but for

\footnotetext{
$20 \quad$ Ibid Strand 3, para 3.

2I Ibid Strand 3.

22 Ibid Strand 3, para I.

$23 \quad$ Ibid Strand 3, para 3

24 Ibid Strand 2.
} 
the British-Irish relationship. Afterall, the Agreement was negotiated and ratified in the context of the recently created Single European Market (SEM), removing non-tariff obstacles to freedom of movement of goods, services, capitals and people. ${ }^{25}$

EU membership affected the British-Irish relationship in three ways. To begin with, it paradoxically advanced Irish national sovereignty vis-a-vis the $\mathrm{UK}$, where it was once perceived to be an 'un-equal sovereign. ${ }^{26}$ The EU created a more symmetrical relationship, highlighting that Ireland was a state with its own government and policies. In addition, as new EU policies emerged, Ireland and the UK often had common interests and were allies in the EU, for example in taxation and social welfare policies. Finally, the EU created a neutral framework where British and Irish diplomats and politicians met regularly, both formally and informally. One former Irish ambassador to the UK commented that there were on average 25 meetings a day in Brussels where Irish and UK representatives met. ${ }^{27}$

Clearly British-Irish intergovernmental cooperation was central to stability in Northern Ireland and the EU's role was also significant, both normatively and practically. As Jennifer Todd perceptively observed in 20I4:

The settlement in Northern Ireland was achieved and later stabilised only in the context of a strong British-Irish relationship [...] This was a conjunctural achievement of the 1990 s and early 2000s. There was no reason to expect it to be permanent. ${ }^{28}$

Indeed, Todd predicted that 'as attention slips from senior officials and politicians, so the prospects of slippage in the stability of the Northern Ireland settlement increases'. ${ }^{29}$ Although it was not known to Todd and

25 O'Brennan (n 3).

26 Patrick Keatinge, 'Un-Equal Sovereigns: the diplomatic dimension of Anglo-Irish Relations' in PJ Drudy (ed) Ireland and Britain Since 1922 (Cambridge University Press 1984) I39-I6I.

27 Ambassador Daniel Mulhall, evidence to House of Lords European Union Committee, Brexit: UK-Irish relations, $6^{\text {th }}$ Report of Session 2016-17, 42, para 171 .

28 Jennifer Todd, 'The vulnerability of a (quasi-)constitutional settlement: Northern Ireland after 1998 and the British-Irish relationship' (2014) Working Paper II2, Institute for British-Irish Studies, University College Dublin, 20.

29 Todd (n 28) 20. 
others at the time, an event a few years later would indeed have the potential to remove attention away from Northern Ireland and the peace process. In the next section, the challenges of this event - Brexit - to intergovernmental cooperation are summarised and an analysis of Brexit's impact to date is provided.

\section{BREXIT'S CHALLENGES TO THE BRITISH-IRISH RELATIONSHIP}

Brexit posed various challenges to the British-Irish relationship: first, a potential resurgence of the Irish unification issue; second, potential damage to the Belfast/Good Friday Agreement; third, the creation of conflicts of interest; and fourth, the removal of the EU framework for cooperation.

\section{Irish Unification}

As noted by Connelly and Doyle in this special issue, ${ }^{30}$ the Belfast/Good Friday Agreement sought to detoxify the issue of unification by providing a settlement that attempted to reflect both unionist and nationalist voices and had no pre-determined outcome. Opinion surveys repeatedly show that nationalists are happy to remain in the UK under the Belfast/Good Friday Agreement's provisions. In addition, the data shows that the largest portion of people in Northern Ireland identify themselves as neither unionist nor nationalist. ${ }^{31}$ However, under the Belfast/Good Friday Agreement, if a majority in Northern Ireland support Irish unification, then both governments are obliged to legislate for unification. ${ }^{32}$ However, the nationalist community's support for Remain during the Brexit referendum raised immediately the issue of Irish unification with the argument being made that if there was unification, Northern Ireland could stay in the EU. Sinn Fein called for a border poll and although they wavered in their emphasis

3o Eileen Connelly and John Doyle, 'Brexit and the Irish Border' in this Special Issue.

31 Katy Hayward and Cathal McManus, 'Neither/Nor: the rejection of Unionist and Nationalist identities in post-Agreement Northern Ireland' (2019) Capital and Class.

32 John Doyle and Eileen Connolly 'Brexit and the Northeen Ireland Question' in Federico Fabbrini (ed) The Law and Politics of Brexit (Oxford University Press 20I7) 153 . 
on a poll, ${ }^{33}$ clearly Brexit affected the likelihood of unification to some degree. The fact that a majority of the electorate in Northern Ireland and an overwhelming majority of nationalists ${ }^{34}$ voted to remain in the EU also implied that the Irish government had a role in voicing concerns from nationalists in Northern Ireland.

There is a broad consensus that the time is not ripe for a poll on unification. It is unclear whether there would be a majority in favour, as opinion poll data shows a on average a 50 per cent support base for it in Northern Ireland, ${ }^{35} \mathrm{but}$ with a large number of 'Don't Knows' who could vote either way. Indeed a poll in May 2018 showed that only 42 per cent of Catholics supported a united Ireland..$^{6}$ In addition, although opinion polls show that 64 per cent of the electorate in Ireland would support unification, ${ }^{37}$ when the caveat is added that this could mean higher taxes, support falls. A recent report stated that living standard in Ireland would fall by 15 per cent in the event of unification, if Northern Ireland lost its eleven billion euro subvention from the UK. ${ }^{8}$ There would be significant institutional change in the event of unification, most likely creating a federal state, with parliaments in Belfast and Dublin.

33 'Irish Times View On Sinn Fein's U-Turn on Border poll', Irish Times (2 August 20I8)<https://www.irishtimes.com/opinion/editorial/irish-times-view-on-sinnféin-s-u-turn-on-a-border-poll-I.358343I > accessed I4 September 2019.

34 Connolly and Doyle (n 30).

35 Bill White, 'Poll Suggests Gradual Shift to united Ireland', Irish Times (I October 20I8) <https://www.irishtimes.com/opinion/polls-suggest-gradual-shift-to-unitedireland-I.36452I4> accessed I4 September 2019.

36 Sam McBride, 'New poll finds just 21\% support for a united Ireland, despite fears about post-Brexit Irish border', iNews (2I May 2018) <https://inews. co.uk/news/politics/new-poll-finds-just-2I-support-for-a-united-ireland-despitefears-about-post-brexit-irish-border/> accessed I4 September 2019.

37 'Irish Times View on All-Ireland Poll', Irish Times (7 March 2019) $<$ https://www.irishtimes.com/opinion/editorial/irish-times-view-on-all-irelandpoll-politics-and-people-diverge-on-brexit-I.3818230?mode=sample\&authfailed=I\&pw-> accessed I4 September 2019.

$3^{8}$ Eoin Burke-Kennedy, 'United Ireland would see living standards in Republic fall by $15 \%$ ', Irish Times (15 September 15 2018) <https://www.irishtimes.com/business/ economy/united-ireland-would-see-living-standards-in-republic-fall-by-I5-I.36297 48 ? mode $=$ sample\&auth-failed=I\&pw-origin $=$ https $\% 3 \mathrm{~A} \% 2 \mathrm{~F} \% 2 \mathrm{Fwww}$.irishtimes. com\%2Fbusiness $\% 2$ Feconomy $\% 2$ Funited-ireland-would-see-living-standards-inrepublic-fall-by-I5-I.3629748> accessed I4 September 2019. 
However, this would undoubtedly involve onerous change administratively and institutionally and probably create pressure for greater decentralisation of the highly centralised Irish state. It is precisely these questions that are becoming the focus of academic attention. ${ }^{39}$ However, all the main parties in Ireland are aware that a poll on unification would further destabilise and polarise Northern Ireland and do not want to aggravate the new tensions created by Brexit.

\section{The Belfast/Good Friday Agreement}

Although an unintended and indirect consequence of Brexit, following the June 2017 UK election, the DUP's Confidence and Supply arrangement with the Conservative-led UK government immediately brought into question the UK's role, enshrined by the Belfast/Good Friday Agreement, as an honest neutral broker in the politics of Northern Ireland. The DUP's pivotal position in the UK government contributed to provocative language from the Taoiseach Leo Varadkar. For example, in December 2017 he stated that 'no Irish government will ever again leave Northern nationalists and Northern Ireland behind.' 40

More specifically, as Connelly and Doyle note in this special issue,$^{4 \mathrm{I}}$ Brexit potentially undermines Strand 2 of the Belfast/Good Friday Agreement, by creating a hard border between Northern Ireland and Ireland, thereby damaging cross-border cooperation. It was also unclear whether EU funding to Northern Ireland would continue. ${ }^{42}$ Thus, from June 2016, the Irish

39 For example, there are two recently launched research projects: John Coakley, Paul Gillespie, Jennifer Todd, 'Constitutional Futures After Brexit', Institute for British-Irish Studies, University College Dublin, available at $<$ https://www.ucd.ie/ibis/newsevents/> and Alan Renwick et al, 'Unification Referendums on the Island of Ireland', The Constitution Unit, University College London.

40 Marie O'Halloran, 'Varadkar clarifies 'offensive' remark on Northern Ireland', Irish Times (I2 December 20I7) <https://www.irishtimes.com/news/politics/ oireachtas/varadkar-clarifies-offensive-remark-on-northern-ireland-I.332523I > accessed I4 September 2019.

4I Connelly and Doyle (n 30).

42 Jonathon Tonge, 'The Impact of Withdrawal from the European Union upon Northern Ireland' (2016) 87(3) Political Quarterly 338 - 342. 
government lobbied vigorously for four priorities to be included in the EU's Brexit bargaining agenda: first, to maintain the 1948 Common Travel Area (CTA) between Ireland and the UK; second, to protect the Belfast/Good Friday Agreement; and third, to protect a soft border between Northern Ireland and Ireland - freedom of movement of trade and services and to protect the rights of Irish citizens in the UK. ${ }^{43}$

Fourthly, the Irish government lobbied to ensure that these issues would be resolved in the withdrawal negotiations and not form part of the negotiations on the future trading relationship between the UK and the EU. In other words, the negotiations about Northern Ireland and about the EU-UK future trading relationship respectively would occur sequentially, not simultaneously. The Irish government suspected that, if simultaneous negotiations occurred, the UK government would use the Northern Irish issue as a bargaining chip to gain trade concessions from the EU. In such a bargaining game, it was feared that a soft border could be sacrificed in the final outcome.

\section{Trust issues and conflicts of interest}

Thus, Brexit immediately lessened trust between both governments by placing them on opposite sides of the table in the negotiations. It also revealed a divergence between both governments in their emphasis on Northern Ireland. Connelly and Doyle show how this divergence was obvious from the period of the Brexit referendum campaign onwards. ${ }^{44}$ One adviser to David Cameron reported how the then UK leader refused to include the negative impact of a Brexit vote on Northern Ireland in the Brexit campaign. ${ }^{45} \mathrm{After}$ the referendum, although many UK politicians were aware of the serious implications for Northern Ireland, not least the House of

43 Etain Tannam, 'Intergovernmental and Cross-Border Cooperation: the Good Friday Agreement and Brexit' (2018) I7(3) Ethnopolitics 255.

44 Connelly \& Doyle (n 30).

45 Matthew O'Toole, 'Ireland an afterthought during Brexit campaign when I was Cameron adviser', Irish Times (4 October 2017) <https://www. irishtimes.com/opinion/ireland-an-afterthought-during-brexit-campaign-when-iwas-cameron-adviser-I.3242732> accessed I4 September 2019. 
Lords Brexit committee ${ }^{46}$ it was only under Irish governmental influence that the UK government began to focus at all on Northern Ireland. Even then there were various reports that some Conservative politicians believed the EU would not prioritise Northern Ireland, once the UK agreed its 'divorce bill' with the EU. Similarly, there were reports that UK politicians believed that the EU's support for the Irish government's position would waver and, as a consequence, UK officials lobbied in EU capitals in an effort to 'divide and conquer' EU states. ${ }^{47}$ These very different and conflictual perceptions created a new cleavage between UK and Irish governments and periodically contributed to blunt megaphone diplomacy not heard since the 1980 s, for example during the $\mathrm{H}$-Block hunger strikes in $198 \mathrm{I}$.

The incompatibility between the UK leaving the EU, including its customs union and single market, and maintaining an open border in the island of Ireland made a bespoke solution, or special status for Northern Ireland the only possible solution in the negotiations. The so-called 'backstop' in the Withdrawal Agreement, negotiated by Theresa May's government and the $\mathrm{EU}$, was immediately opposed by unionists ${ }^{48}$ and by Brexiteers who argued it undermined Northern Ireland's constitutional status in the UK. Thus, by March 2019, sources of tension in the British-Irish relationship coalesced around the backstop's inclusion in the Withdrawal Agreement, despite the fact that Theresa May and her team had agreed the backstop with the EU in the negotiations.

Worryingly, although all attention was focused on the backstop and the border issue, Brexit also posed other deep long-term challenges to the British-Irish relationship. Almost immediately after the 2016 referendum, there were implications for trust and sharing of information between both governments. The Irish government feared that Northern Ireland would be used as a pawn by the UK government to achieve a more favourable final trade

${ }^{46}$ House of Lords, "Brexit Inquiry", Brexit and British-Irish Relations, House of Lords, London, I2 December 2016.

47 Daniel Boffey, 'UKs pre-summit push to 'divide and rule EU27' impeded Brexit talks', The Guardian (29 October 2017) <https://www.theguardian.com/politics /2017/oct/29/uks-pre-summit-push-to-divide-and-rule-eu-27-impeded-brexittalks $>$ accessed I4 September 2019.

48 Doyle and Connolly (n 32). 
deal for the UK. For that reason it successfully lobbied the other EU Member States and the Commission to ensure that trade talks and the withdrawal agreement were not negotiated simultaneously, as the UK government preferred, but sequentially. The border issue must be resolved first before trade talks could begin. This preference was immediately at odds with UK preferences, again creating tension between both governments.

\section{Removal of EU framework for cooperation}

A fourth challenge is that the opportunities for communication offered by the EU will vanish with Brexit. The frequency with which British and Irish officials and politicians met with each other in Brussels will be difficult to replicate when the UK leaves the EU. Moreover, when the UK leaves, Ireland will lose an ally in the EU. Both governments often converged in their attitudes on a number of EU issues, including taxation and social policy. Ireland relied on the UK to serve its cause. The absence of that informal alliance removes a pillar of cooperation from the bilateral relationship.

The challenges posed by Brexit were aggravated by the collapse of the Northern Ireland Executive in January 2017, by a weak and divided UK government in disarray, relying on the DUP after the June 2017 election, and by Jeremy Corbyn's lacklustre support for the EU. The challenges took their toll on the British-Irish relationship. Since June 2016 there have been three main periods in the British-Irish relationship, where tensions have ebbed and flowed. As the next paragraphs show these tensions have heightened at specific times.

\section{BREXIT AND THE BRITISH-IRISH RELATIONSHIP, 20I6-20I9}

In the immediate aftermath of the Brexit referendum result the Irish government was clearly deeply disappointed, but the rhetorical response was low-key. Enda Kenny, then Taoiseach, issued a statement pledging to adopt 'the same spirit of partnership that has underpinned the peace process and has transformed relationships on this island since the Good Friday Agreement'49 and emphasised how he and David Cameron 'worked closely

49 Enda Kenny, 'Statement by An Taoiseach, Enda Kenny TD, on the UK Vote to

Leave the European Union' (Merrionstreet.ie, 24 June 2016)


together at a time of unprecedented warmth in relations between our two countries.' 50

However, the issue of Irish unification raised its head quickly. In July 2016, Enda Kenny stated that a border poll on Irish unity should be considered because a majority of the Northern Ireland electorate voted to remain in the EU. ${ }^{\text {II }}$ Both Fianna Fáil and Sinn Féin called for a border poll. Sinn Féin later said that unification was a long term strategy, implying it did not want a poll quickly. Fianna Fáil and the Irish government also ceased mentioning it, although Fianna Fail initiated a study of different options for Irish unification.

Overall, the aftermath of the Brexit referendum was marked by a noticeable lack of engagement from the UK government, contributing to an increasingly strained relationship. ${ }^{2}$ In addition, the UK government sought to divide and conquer EU states so as to undermine the Irish government's lobbying efforts to prioritise the border issue and agree on that priority first before moving to trade negotiations. In April 2017, the then Minister for Foreign Affairs, Charlie Flanagan, expressed frustration at the UK government's failure to communicate directly with the Irish government. ${ }^{53}$ A significant change in the conduct of relations was highlighted by the UK government's announcement via the UK Embassy in Dublin that it was withdrawing from the 1964 Fisheries Convention that allowed fishing in coastal waters from the coast. The Irish Minister for Agriculture stated that he had only learnt of the

$<$ https://merrionstreet.ie/en/News-Room/Speeches/Statement_by_An_ Taoiseach_Enda_Kenny_TD_on_the_UK_Vote_to_Leave_the_European_Unio n.html $>$ accessed ${ }_{4} 4$ September 2019 .

5o Enda Kenny (n 48).

${ }^{51} \quad$ Pat Leahy, 'Kenny Says Border Poll Should Be Considered in Brexit Talks', Irish Times (I6 July 20I6) <https://www.irishtimes.com/news/politics/kenny-saysborder-poll-should-be-considered-in-brexit-talks-I.2726382> accessed I4 September 20I9.

52 Mary C Murphy, Europe and Northern Ireland's Future: negotiating Brexit's Unique Case (Agenda 20I8) II5.

53 Pat Leahy, 'Minister criticises British government over Brexit strategy' Irish Times (24 December 20I6) <https://www.irishtimes.com/news/politics/ministercriticises-british-government-over-brexit-strategy-I.29I68I9> accessed I4 September 2019. 
decision from media channels, despite having met with the UK Minister for Agriculture about the Convention in early July. ${ }^{54}$

Similarly, in July 20I7, the Taoiseach Leo Varadkar spoke bluntly in a media briefing stating that ' $[\mathrm{w}$ ]hat we' re not going to do is to design a border for the Brexiteers because they're the ones who want a border. If anyone should be angry it's us, quite frankly.'55 Whereas in the 1990s, both governments consulted with each other before making statements of relevance to the relationship, in September 2017, the then Minister for Foreign Affairs Simon Coveney stated his government's opposition to any technical solutions to the Irish border, thereby for the first time explicitly opposing the UK government's policy statement about the border.

The UK government's official response was muted and in that way tensions did not escalate. However, it was the absence of direct communication from the UK and the infrequency of prime ministerial meetings that often aggravated tensions. Theresa May and the then Taoiseach Enda Kenny had two meetings from June 2016 to January $2017,{ }^{56}$ which given the potential impact of Brexit on Ireland and Northern Ireland was lower than might be expected. The UK government frequently stated that they were wedded to a frictionless border and that there would be no return to the borders of the past. However, there was no engagement about how to achieve that aim in the context maintaining the integrity of the EU single market. In addition, some UK media depictions of Ireland and of the Taoiseach became negative at times and some Irish media analyses of the UK also reverted to stereotypes of 'lost empire'.

54 'British ban on foreign trawlers 'unhelpful', says Creed', Irish Times (2 July 2017) $<$ https://www.irishtimes.com/news/environment/british-ban-on-foreign-trawlersunhelpful-says-creed-I.3140783> accessed I October 2019.

55 'Ireland "will not design a border for the Brexiteers", says Taoiseach', The Guardian (28 July 2017) <https://www.theguardian.com/world/2017/jul/28/taoiseach-leovaradkar-ireland-not-design-border-brexiteers $>$ accessed I4 September 2019.

56 Department of Taoisseach, available at $<$ https://merrionstreet.ie/en/search/?cof =FORID:0I3I257733I47I236I8I8:nn3augegkg4\&ie=UTF-8\&q=meetings\%2owith $\%$ 2otheresa\%2omay>. 
The Irish government's concerted lobbying effort succeeded, as Connelly and Doyle note. ${ }^{57}$ The EU made it clear that the Brexit negotiations would not move on to future trade relations unless the Irish government was satisfied about the Northern Ireland border issue..$^{8}$ Indeed, as Fabbrini has noted, the EU has been remarkably united in its approach to Brexit. 59 The EU stated that all issues would have to be addressed to the satisfaction of the EU before phase two of the negotiations would be dealt with. The EU's strong commitment to the border issue contributed to increased British engagement with the issue. However, despite the many sources of tension and the above examples of negative political rhetoric, there was a noticeable decline in megaphone diplomacy from December 2016 to December 2018, as the next section shows.

First of all, the EU's commitment to Northern Ireland influenced the UK government's Position Paper on Northern Ireland in August 2017. ${ }^{60}$ Although the paper was short on detail, it dealt with each EU priority systematically and pledged to have no physical infrastructure on the border. The Irish government welcomed it cautiously, stating there were still unanswered questions and from this period onwards, while lobbying intensively, the Irish Minister for Foreign Affairs particularly was at pains to show an understanding of Theresa May's domestic constraints. ${ }^{6}$ However, there were no prime ministerial meetings and continued weakness in

$57 \quad$ See Connelly \& Doyle (n 30).

$5^{8} \quad$ 'Ireland will have final say on progress of Brexit talks, says EU', The Guardian (I December 2017) <https://www.theguardian.com/politics/20I7/dec/or/ireland-willhave-final-say-on-progress-of-brexit-talks-says-eu> accessed I4 September 20 I9.

59 Federico Fabbrini, 'The Future of the EU 27 ' in Federico Fabbrini (ed) The Law and Politics of Brexit, 2nd ed (Oxford University Press 2019).

60 'Position Paper on Northern Ireland', (Gov.uk, I6 August 20I7) $<$ https://www.gov.uk/government/publications/northern-ireland-and-ireland-aposition-paper $>$ accessed I4 September 2019.

6r 'Coveney says Brexit deal can be sold persuasively over two-and-a-half weeks', Irish Times (26 November 2018) <https://www.irishtimes.com/news/ireland/irishnews/coveney-says-brexit-deal-can-be-sold-persuasively-over-two-and-a-halfweeks-I.37II 280 ? mode=sample\&auth-failed=I\&pw-origin=https $\% 3 \mathrm{~A} \% 2 \mathrm{~F} \% 2 \mathrm{Fww}$ w.irishtimes.com $\% 2$ Fnews $\% 2$ Fireland $\% 2$ Firish-news $\% 2$ Fcoveney-says-brexitdeal-can-be-sold-persuasively-over-two-and-a-half-weeks-I.37II280> accessed I October 20I9. 
developing joined-up high level engagement on the UK side. Moreover the UK government's Florence Speech in September 2017 was regarded in Dublin as a disappointment, as it devoted very little attention to the Northern Ireland issue. ${ }^{62}$

In contrast, in December 2017 a joint report between the EU and UK negotiators was published, ${ }^{63}$ following a delay caused by DUP opposition. ${ }^{64}$ It included a commitment to a backstop solution to the Irish border if the UK left the customs union and the single market. The solution was that if the UK did leave the customs union and the single market, Northern Ireland would remain aligned to the EU single market rulebook and hence trade freely with Ireland and the rest of the EU. Regulatory alignment would occur to ensure Northern Irish goods were subject to EU quality standards. The December 2017 joint report was welcomed by the Irish government and its key provisions were included in the final draft Withdrawal Agreement published in November 2018.65

The interim period from December 2017 to November 2018 was characteristically volatile, but in general saw a marked decline in negative rhetoric from the Irish governments. This was despite the particularly stressful European Council summit in Salzburg in September 2018, when Theresa May gave a stark uncompromising speech in response to the EU rejecting the UK government's White Paper - the Chequers Plan. ${ }^{66}$ In

62 Etain Tannam, 'Theresa May's Florence speech and Northern Ireland: subtle change?' LSE Brexit Blog (29 September 2017) <https://blogs.lse.ac.uk/ brexit/2017/og/29/is-the-negative-tide-of-british-irish-relations-receding/> accessed I4 September 2019.

63 European Commission, Joint Report (8 December 2017), available at $<$ https://ec.europa.eu/commission/sites/beta-political/files/joint_report.pdf >.

64 Tony Connelly, Brexit and Ireland: the dangers, the opportunities and the inside story of the Irish response (Penguin 2017).

65 'Draft Agreement on the withdrawal of the United Kingdom of Great Britain and Northern Ireland from the European Union and the European Atomic Energy Community, as agreed at negotiators' level' (I4 November 2018), available at $<$ https://ec.europa.eu/commission/sites/beta-political/files/draft_withdrawal_ agreement_o.pdf $>$.

66 Policy Paper The future relationship between the United Kingdom and the European Union, (Gov.uk, I7 July 2018) <https://www.gov.uk/government/publications/the-future- 
addition, the Irish Tánaiste Simon Coveney explicitly emphasised that 'the challenges of these Brexit negotiations should never be twisted into tools for a constitutional agenda for Northern Ireland, ${ }^{167}$ thereby rejecting using unification as a political football.

In November 20I8, the Withdrawal Agreement between the UK and the EU was finally announced amid moving responses from both Leo Varadkar and Simon Coveney. The former stated that 'I want to acknowledge Prime Minister May's integrity in honouring her promise to protect the Peace Process and the Good Friday Agreement. And her commitment to avoid a hard border. She has been true to her word' ${ }^{68}$

Yet, the period of relief was short-lived, as immediately the Irish government's success in EU bargaining was met with wrath by Brexiteers. ${ }^{69}$ In February 20I9, continuing disarray in the UK parliament's ratification process led to Theresa May supporting the Brady Amendment. ${ }^{70}$ This called for the removal of the backstop form the Withdrawal Agreement, thus reneging on the Withdrawal deal she herself had agreed with the EU in November 20I8. Her apparent reneging on the Withdrawal Agreement led to hard-line rhetoric once more from both Simon Coveney and Leo Varadkar.

Theresa May requested that she meet with Leo Varadkar in Dublin on 8 February 2019, following her meeting in Brussels the day before, and reports stated that the meeting was cordial and useful..$^{71}$ An extension of the UK exit

relationship-between-the-united-kingdom-and-the-european-union $>$ accessed I4 September 20I9.

${ }_{67}$ Simon Coveney, 'Tanaiste's Speech at the British-Irish Association Conference', (Oxford, 8 September 2018) Department of Foreign Affairs and Trade.

68 'Statement by Taoiseach Leo Varadkar on Withdrawal Agreement', (MerrionStreet.ie, I4 November 20I8) <https://merrionstreet.ie/en/NewsRoom/News/Statement_by_Taoiseach_Leo_Varadkar_on_Withdrawal_Agreem ent.html $>$ accessed I4 September 2019.

69 See Federico Fabbrini in this Special Issue.

70 House of Commons Order Paper No.24O: Part I, 21, 29 January 2019.

${ }_{71} \quad$ Kevin Doyle, 'No breakthrough' on Brexit deal as Varadkar and May meet in Dublin', Irish Independent (8 February 2019)<https:/www.independent.ie/irishnews/no-breakthrough-on-brexit-deal-as-varadkar-and-may-meet-in-dublin37798007.html > accessed I4 September 2019. 
date to October 3I 2019 was granted by the EU. The hope was that revision of the EU's interpretive statement or political declaration on the future trading relationship would occur and revision of the political declaration was mentioned by one Irish politician in the ruling party Fine Gael. ${ }^{22}$

However, Theresa May announced her resignation on May $242019,{ }^{73}$ with Boris Johnson taking over as Prime Minister in July 2019. As such, divisions in the UK will continue, as shown by the success of the UK Brexit Party in the EP elections in May 2019.

\section{THE FUTURE OF THE BRITISH-IRISH RELATIONSHIP}

The above overview of trends in the British-Irish relationship since 2016 leads to some observations about the relationship during the Brexit era and also some prescriptions for its future management. Brexit has clearly cast a deep cloud over the British-Irish relationship. Relations have not been as tense since the early i980s and political rhetoric that had vanished by the I990 re-emerged. The joined-up thinking and mutual problem-solving that typified the peace process and began in the mid-r98os were not evident. There were no joint statements by both governments and very few joint press conferences after meetings. Indeed, there were very few meetings between both Prime Ministers given the magnitude of the Brexit crisis. The core questions are whether the relationship has been irreparably damaged and how best to manage the relationship after the UK has left the EU.

The escalation in tensions at various times since summer 2016 has been a source of surprise for seasoned observers of the relationship. The speed with which apparently deep cooperation regressed was startling. While the above section has highlighted that both governments attempted to manage the relationship diplomatically and hard-line language was only used for strategic

${ }^{2}$ Neale Richmond, RTE Prime Time (I2 March 20I9), available at $<$ https://www.rte.ie/player/series/prime-time/SIooooooo825? epguid=IHoo0368 I77> accessed I4 September 2019.

73 Denis Staunton, 'May Defiantly Defended Record Before Her Voice Began To Crack', Irish Times (25 May 2019) <https://www.irishtimes.com/news/world/uk/ defiance-as-may-defends-record-before-her-voice-begins-to-crack-I.3903650> accessed 8 October 2019. 
reasons, there has been a clear departure from the cooperative intergovernmentalism that began in the mid-I980s.

Specifically, the British-Irish Intergovernmental Conference did not meet regularly in the ten years before the Brexit referendum. This weakness is partially explained by a reduction in the number of non-devolved policy areas in Northern Ireland following the 2006 St Andrews Agreement. ${ }^{74}$ However, it also reflected a deeper weakness in implementing the Good Friday Agreement that stemmed from both governments placing less priority on Northern Ireland. Although the peace process 'brought a new British-Irish rhetoric of "best friends" [...] the informal British-Irish mode of implementing the Agreement [...] was dependent on the states' prioritisation of Northern Ireland. After 20I0 this weakened. ${ }^{15}$ Given its sensitivity for unionists, the failure to meet regularly in a routine way made it far harder to resurrect it post-20i6. Yet it was the obvious institution for both governments to discuss Brexit's challenges.

The British-Irish Council did meet regularly. Indeed by 2017 it had met 29 times and had produced 'a formidable volume of useful reports' ${ }^{176}$ on policy areas of common interest. However, its 'precise value is unclear.' ${ }^{77}$ It is purely consultative and no UK Prime Minister has attended its meetings since Tony Blair. ${ }^{78}$ Indicative of the greater attention paid to Northern Ireland by Irish governments, all Irish Taoisigh have attended the British-Irish Council meetings since its creation.

The Brexit era has shown that British-Irish cooperation was not as embedded as previously assumed. In fact, it highlighted that although the Belfast/Good

74 John Coakley, 'British-Irish Institutional Structures: towards a new relationship' (20I4) 29(I) Irish Political Studies 8I.

75 Jennifer Todd, 'The Vulnerability of the Northern Ireland Settlement: BritishIrish Relations, Political Crisis and Brexit' (2015) 40(2) Etudes irlandaises 4.

$7^{6}$ John Coakley 'The British-Irish Relationship in the $2 \mathrm{I}^{\text {st }}$ Century' in Tannam (ed) Beyond the Good Friday Agreement: in the midst of Brexit (London Routledge 2018) 97.

77 Mary C Murphy, Europe and Northern Ireland's Future: negotiating Brexit's Unique Case (Agenda 2018) I07.

${ }^{8}$ Etain Tannam, 'Intergovernmental and Cross-Border Cooperation: the Good Friday Agreement and Brexit', in Tannam (ed) Beyond the Good Friday Agreement: in the midst of Brexit (London Routledge 2018) 27. 
Friday Agreement and its accompanying British-Irish Agreement are international treaties, there was no obligation that the British-Irish Intergovernmental Conference would meet regularly. There was a set schedule for meetings of the North South Ministerial Council, subject to Strand I institutions being in place, and there was also a set schedule for the British-Irish Council. However, there was no legally binding schedule for British-Irish Intergovernmental Conference meetings. The frequency of meetings is therefore a function of political will and given potentially 'grave clashes of interest' between the British and Irish sides, there is potential for deterioration in the relationship as the Brexit negotiations proceed. ${ }^{79}$ These clashes of interest are also likely after the Brexit era, given the UK's absence from the EU.

Although not directly related to Brexit, a stark warning of the need for legally binding agreements occurred in June 2019 when the Scottish government called for the Irish government to call on Irish fishermen fishing off Rockall island to cease fishing immediately within the $\mathrm{I} 2$ mile exclusion zone, or face enforcement action. ${ }^{80}$ Rockall is between Donegal and Scotland and is by agreement part of UK sovereign territory. However the Irish government claims that Rockall is part of EU fisheries policy giving equal access to both states. In practice the issue was ignored for decades and according to Donegal politicians, Irish fishermen had not increased their fishing activities at Rockall, but the Scottish action highlighted how issues can escalate when contextual conditions alter. ${ }^{8 \mathrm{r}}$ The SNP-led Scottish government is proremain, but the Scottish fishing community supports Brexit. Arguably the Scottish government behaved in an adversarial manner about Rockall to gain the fishing community's support despite the SNP's remain stance.

In addition, post-Brexit, there will be an obvious temptation for UK governments to lobby Irish governments to influence the EU in the UK's

79 Coakley (n 76) 99.

8o 'Fisheries Dispute Breaks out Between Ireland and Scotland', RTE News (8 June 2019) <https:/www.rte.ie/news/2019/0607/1054IIo-fishing-dispute-rockall/> accessed I4 September 2019.

${ }_{8 \mathrm{r}}$ There was no reference made by the Scottish government to any connection between the UK withdrawal from the 1964 Fisheries Convention and the Rockall issue. 
favour on specific policy issues, but Irish governments will resist such efforts, potentially causing more tension.

The risks to future relations necessitate a more formalised relationship. A key condition for future British-Irish cooperation is that regular prime ministerial meetings occur and that the Belfast/Good Friday Agreement's institutions are used robustly. Since 2006, Strand I received far more attention politically than the other strands of the Belfast/Good Friday Agreement. For many, Strands 2 and 3 were a package deal to placate nationalists who wanted strong cross-border institutions (Strand 2) and Unionists who wanted East-West institutions (Strand 3). However, as this article has shown, the concept of the totality of the relationship and John Hume's strategy emphasised all three strands working in tandem. Indeed, the peace process and the success of Strand I rested on close British-Irish cooperation.

As table I shows, Theresa May and Leo Vardakar met nearly every month from February 2018 to February 2019. However, it is equally evident that if the EU had not prioritised the Northern Irish issue, it would have been far more difficult to engage the UK Prime Minister's attention. 
Table I. Meetings between Theresa May and Leo Varadkar, February 2018-February $2019^{82}$

\begin{tabular}{|c|c|}
\hline \multicolumn{2}{|c|}{ February 2018} \\
\hline $\mathrm{I}^{\text {th }}$ & Meeting with PM May, Stormont House, Belfast \\
\hline \multicolumn{2}{|c|}{ March 2018} \\
\hline $22^{\text {nd }}-23$ rd & $\begin{array}{l}\text { March European Council - Taoiseach meets with PM } \\
\text { May in margins. }\end{array}$ \\
\hline \multicolumn{2}{|l|}{ May 2018} \\
\hline $17^{\text {th }}$ & $\begin{array}{l}\text { Taoiseach met with PM May in the margins of the EU- } \\
\text { Western Balkans Summit in Sofia. }\end{array}$ \\
\hline \multicolumn{2}{|l|}{ June 2018} \\
\hline $28^{\text {th }}$ & Taoiseach met with PM May at European Council \\
\hline \multicolumn{2}{|c|}{ September 2018} \\
\hline $2 \mathrm{O}^{\text {th }}$ & $\begin{array}{l}\text { Taoiseach and MoS EU McEntee meet with PM May } \\
\text { (Informal European Council, Salzburg) }\end{array}$ \\
\hline \multicolumn{2}{|c|}{ October 2018} \\
\hline $17^{\text {th }}$ & $\begin{array}{l}\text { Taoiseach meets bilaterally with PM May in margins of } \\
\text { European Council }\end{array}$ \\
\hline \multicolumn{2}{|c|}{ November 2018} \\
\hline $25^{\text {th }}$ & $\begin{array}{l}\text { Taoiseach spoke briefly with PM May on the margins at } \\
\text { Special European Council meeting (Art 50) }\end{array}$ \\
\hline \multicolumn{2}{|c|}{ December 2018} \\
\hline $13^{\text {th }}$ & Taoiseach met with PM May at European Council \\
\hline \multicolumn{2}{|c|}{ February 2019} \\
\hline $8^{\text {th }}$ & Taoiseach met with PM May in Farmleigh House \\
\hline $25^{\text {th }}$ & Taoiseach met with PM May at Arab-EU Summit \\
\hline
\end{tabular}

82 Source: Department of Taoiseach, Dublin. 
The voluntary basis to the British-Irish Intergovernmental Conference is at odds with the EU model of cooperation so espoused by John Hume and oftcited after the Belfast/Good Friday Agreement was signed. Specifically, the European Council - representing EU Heads of State and Government and analogous to the British-Irish Intergovernmental Conference - is obliged to meet at least every six months under Article 15(3) of the Treaty on European Union, and in fact practically meets almost every other month. According to institutionalist logic and John Hume's strategy, the decline in communication after June 2016 and the resurrection of tension in the BritishIrish relationship require institutionalised formalised meetings. Therefore, as a minimum requirement for helping to ensure future British-Irish cooperation, the British-Irish Intergovernmental Conference should be legally obliged to meet at regular intervals.

More robust use of the Belfast/Good Friday Agreement's bilateral institutions, while a necessary condition for future cooperation, is not necessarily sufficient. The EU's dense institutional framework and extensive policy competence implies that a multi-layered institutional framework is needed for British-Irish cooperation to continue and deepen. Therefore, as well as greater use of the Agreement's bilateral institutions, and agreements related to areas of common British-Irish concern, for example the CTA, energy and infrastructure, provided they do not encroach on EU policy competence, would help emulate the EU's policy framework.

Although a Strand 2 cross-border institution, the North South Ministerial Council provides a template for organising sectoral cross-border meetings. Six cross-border bodies were created, following unionist pressure to minimise the number of bodies created: the Trade and Business Development Body (Intertrade Ireland), Waterways Ireland, the Food Safety Body (Safefood), Foyle, Carlingford and the Irish Lights Commission, The Language Body, and the Special EU Programmes Body (SEUPB). ${ }^{83}$ In addition, six areas of cooperation, without joint bodies, were identified: I) Agriculture: Common Agricultural Policy issues, Animal and Plant Health

83 NSMC, 'North South Implementation Bodies' (2016) < https://www.north southministerialcouncil.org/content/north-south-implementation-bodies)>. 
Policy and Research Rural Development; 2) Education: Education for children with special needs, educational under-achievement, teacher qualifications and school, youth and teacher exchanges; 3) Environment: Environment protection, pollution, water quality management and waste management in a cross-border content; 4) Health: Accident and emergency planning, co-operation on high technology equipment, cancer research and health promotion; 5) Tourism including Tourism Ireland: The promotion of the island of Ireland overseas as a tourist destination via the establishment of a new company, known as Tourism Ireland; and 6) Transport: Cooperation on a strategic road and rail infrastructure and public transport ${ }^{84}$

Before the creation of the NSMC, administrative cooperation between officials was patchy. Indeed there were conflicts of interest between many departments, north and south of the border. However, gradually after the establishment of the NSMC, cooperation flourished, despite the many problems caused by the collapsed Executive and by unionist suspicion of cross-border cooperation. Although policy dynamism did not develop for Northern Irish political reasons, contacts between civil servants were reported in some sectors to be strong, for example in agriculture. Table 2 shows the web of cooperation across the civil service caused by preparation for NSMC sectoral meetings.

${ }_{4}$ NSMC, 'Areas of cooperation' (2016) < https://www.northsouthministerial council.org/areas-of-cooperation)>. 
Table 2. Civil Service Cooperation Under NSMC ${ }^{85}$

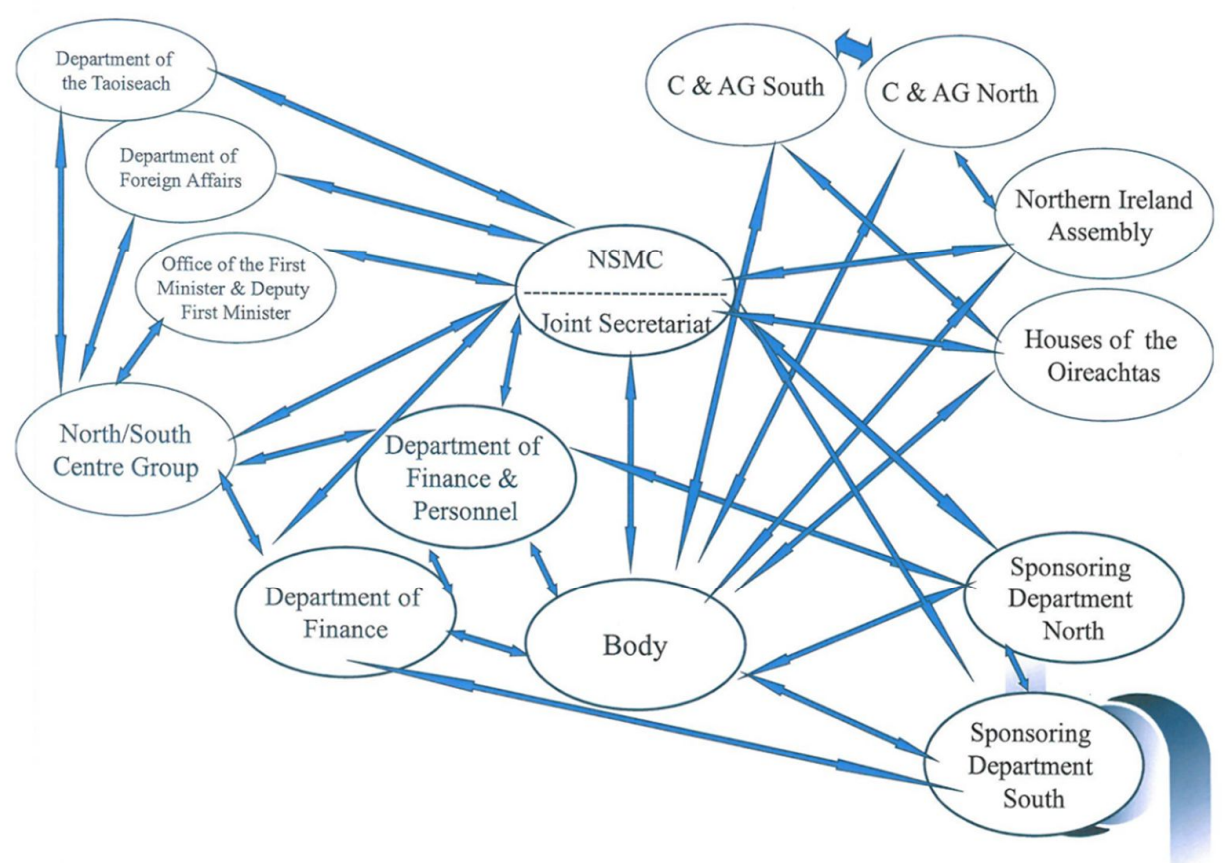

A series of bilateral sectoral agreements in areas of common concern, obliging officials and ministers to meet regularly, could emulate the NSMC idea, without necessitating a coordinating institution.

It is likely that both governments will support increased legalisation of current arrangements. Indeed, Simon Coveney stated that the British-Irish Intergovernmental Conference in July 2018 'will take forward proposals for future East-West cooperation [...] this should be comprehensive across all policy areas of shared concern and should culminate in meetings at the highest political levels'. ${ }^{86}$ Similarly, Theresa May stated that

we already have the British-Irish Intergovernmental Conference and regular Summits between UK and Irish politicians. But as we leave the European

${ }_{55}$ Source: Etain Tannam, British-Irish Relations in the 2Ist Century (Oxford University Press, forthcoming).

86 Coveney (n 67). 
Union, we will need to establish new ways of coming together to develop further our unique relationship. ${ }^{87}$

Clearly, bilateral policy agreements could be established under the BritishIrish Intergovernmental Conference framework. Moreover in May 2019 both governments signed a Memorandum of Understanding to codify the CTA. ${ }^{88}$

Overall, cooperation necessitates a multi-pronged institutional approach to ensure that, at any given time, various civil servants and ministers from both jurisdictions are in both formal and informal contact. Thus, fuller use of the British-Irish Intergovernmental Conference and the British-Irish Council, as well as policy-based bilateral agreements stemming from the British-Irish Intergovernmental Conference would attempt to partially fill the gap left by the UK's departure from the EU.

\section{CONCLUSION}

The future path of the British-Irish relationship is paved with many risks and the optimism of the pre-Brexit era has waned. The period from 2016 to 2019 showed how quickly the habit of cooperation can be reversed, but it also showed how aware senior officials and diplomats are of the need to manage the relationship. In particular the Irish government during this period stepped back from using Irish unification as a political football and Irish diplomats lobbied intensively to ensure that greater attention was paid by the UK government to both Northern Ireland and to the Irish government. Over time, the UK government responded, albeit under pressure from the EU also.

Despite the tensions, both governments are aware that the relationship cannot be taken for granted and, as this article has noted, recently both the UK Prime Minister and the Irish Minister for Foreign Affairs have referred

87 Theresa May, 'PM Speech in Belfast' (Gov.uk, 5 February 2019) $<$ https://www.gov.uk/government/speeches/pm-speech-in-belfast-5-february20I9> accessed I4 September 2019.

88 Denis Staunton, 'British and Irish Governments Sign Common Travel Area agreement', Irish Times (8 May 20I9) <https://www.irishtimes.com/ news/politics/britain-and-ireland-to-sign-common-travel-area-deal-I.3884176> accessed 8 October 2019. 
to the need to make better use of the British-Irish Intergovernmental Conference. It is likely that in securing more robust use of the Strand 3 institutions, the Irish government will lead the efforts, partly because the UK government will have a daunting policy agenda. However, the Irish government has proved adept at lobbying and therefore while the halcyon days of the I990s will not return, the relationship is likely to be relatively cooperative in the decades ahead, 'in the shadow and shelter' ${ }^{189}$ of each other.

89 Simon Coveney citing President Michael D Higgins (n 67). 